\title{
Ergonomics Risk Analysis In Ulos Weaving Workers In The Martimbang And Kebun Sayur Village Pematang Siantar City
}

\author{
Madschen S.M.O.S.S.Tambun \\ ${ }^{1}$ Sari Mulia School of Health Sciences, Banjarmasin, 70233, Indonesia \\ E-mail: siska@stikessarimulia.ac.id
}

Objective: The purpose of this study was to determine the risk of weaver ulos who carried out the work ergonomics in Martimbang and Kebun Sayur Village Pematang Siantar City.

Technology or Method: This was an observational study. The population amounting to 42 people. The level of ergonomics risk related to the body posture, weight, duration, and frequency using REBA tool

Result: Ergonomics risk analysis results using the method of REBA according to the stages of weaving ulos that pull timber is the highest one.

Conclusion: The ulos weaving work in Martimbang Village and Kebun Sayur has four stages of work: putting the pakkan into teropong, stitching, pulling wood and mangampin. The level of ergonomic risk at each stage of work has a different REBA final score. The highest REBA final score was pulling wood and the score was 13 and needs some changes ex: from posture.

Keywords: ergonomics, four stage of work, REBA, ulos weaving workers.

\section{INTRODUCTION}

The national development that has been and will be implemented today, is done through the application of advanced science and technology and has been able to generate job opportunities so that it is expected to improve the socio-economic status and quality of life of family and community. This will work if the risks that will affect the lives of workers, families, and communities can be anticipated. These risks are the possibility of occupational diseases (PAK), occupational illnesses and occupational accidents that can cause disability and death. This anticipation must be done by all parties by means of adjustment between workers, work processes and work environment. This approach is known as the ergonomic approach [1].

$$
\text { Implementation of correct }
$$
ergonomics in the place of work aims to the worker in working always in a healthy, comfortable, safe, productive and prosperous. Conversely, if the application of ergonomics done incorrectly even resulted in the emergence of complaints, occupational diseases of workers due to their work. Consistently, Self-reported Work-related Illness (SWI) in the UK reported that in $2009 / 2010$ it was estimated that the prevalence of 572,000 people in the UK suffered from Musculoskeletal disorders 
caused or aggravated by past work. This data is equivalent to 1900 per 100,000 people (1.9\%) working in the last 12 months in the UK. Of the prevalence, 248,000 people are estimated to suffer from traumatic disorders of the back, 230,000 people suffering from the upper body or neck disorders, and 94,000 people with disturbances in the lower body. From the data about one-third $(188,000$ people) is a new incident. The following is the prevalence of the incidence of Musculoskeletal Disorder in the UK from 2006 to 2010 [2].

Abnormalities of the musculoskeletal system are a major cause of chronic pain and physical abnormalities. The components of the musculoskeletal system may be torn, injured or inflamed. Homsombat \& Chaiklieng, which conducted research on 80 weaving workers in Thailand, reported that $31.3 \%$ complained of neck pain, $28.8 \%$ on the lower back, $25 \%$ on the shoulder and $15 \%$ on the wrist. [3]. Choobineh, who conducted the study in 1439 carpet weaving workers in Iran, reported that $35.2 \%$ complained of neck pain, $47.8 \%$ on the shoulders, $19.2 \%$ on the elbows, $38.2 \%$ on the wrist, $37.7 \%$ on the upper back, $45.2 \%$ on the lower back, $16 \%$ in the thigh, $34.6 \%$ in the knee and $23.7 \%$ in the leg [4]. While Rosalina who conducted research on weaving workers in Jepara, reported that $42.2 \%$ complained of arm pain and $48.9 \%$ on the shoulder [5].

Ulos weaving business is a traditional business that uses traditional facilities and infrastructure. Workers have low levels of education and economics so that in order to meet the needs of life, they have to work hard.

Pematang Siantar City as an urban area there are many economic activities that many done by the community and one of them are weaving industry. This is in line with the regional development agenda that is to strengthen the industrial sector, the development of small and medium enterprises with a focus on labor-intensive industries that are expected to contribute to the increase of people's income, job creation and economic growth. The area that became one of the weaving industry centers is Martimbang Village and Village Vegetable Garden. As one weaving industry center, with this research, is expected to be a pilot for other regions.

From the results of observations in the preliminary survey at Kelurahan Martinci \& Kelurahan Kebun Sayur Kota Pematang Siantar, ulos weaving workers work with seats without a backrest with repetitive leg and hand movements. Looms and seating are designed with no account of the anthropometry of the worker, so the worker must adjust and work with his back bent. Working conditions such as this force the workers to always be on the attitude and position of work that is not natural long lasting and settled or static. Working conditions may cause health problems. A static attitude over long periods of time more 
quickly leads to complaints on the musculoskeletal system.

\section{RESEARCH METHODS}

The design of this study was observational with cross sectional approach. The research will use REBA survey tools.

This research was conducted on ulos woven worker of Martimbang Village and Kelurahan Kebun Sayur Kota Pematang Siantar. The study population was 42 ulos weaving workers.

\section{RESULT}

The result of Ergonomic Level Risk Analysis was attended with 4 stage :

1. Levels of Ergonomic Risk with pakkan

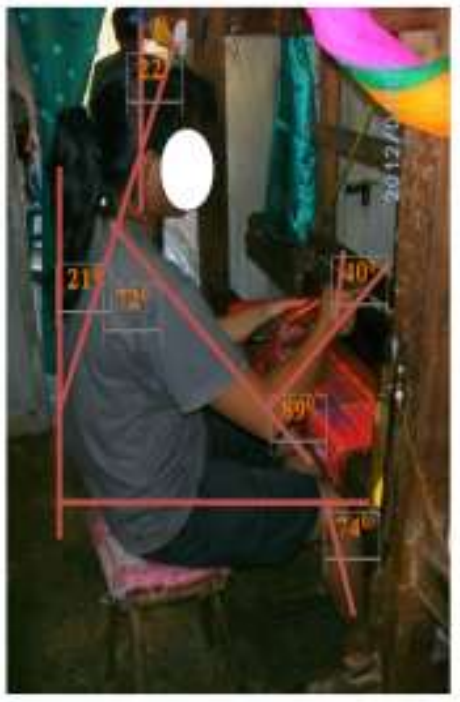

Figure 1 Ergonomic Risk Level Assesment with pakkan

Final REBA score was 7 and it can be interpreted that medium level risk.
2. Levels of Ergonomic Risk with manjungkit

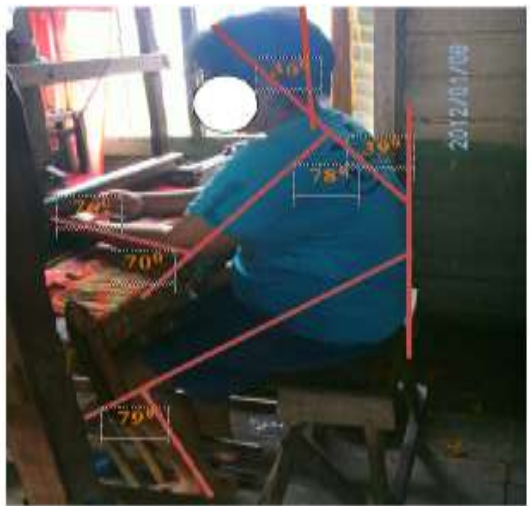

Figure 2 Ergonomic Risk Level Assesment with manjungkit

Final REBA score was 10 and it can be interpreted high-risk level.

3. Levels of Ergonomic Risk with pulling the wood

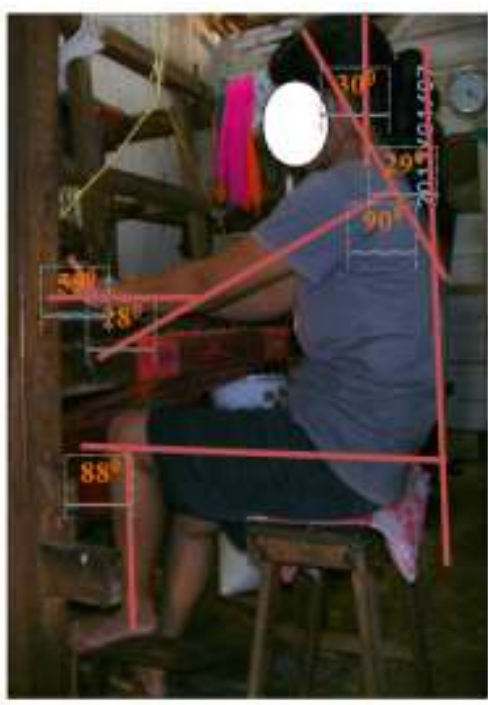

Figure 3 Ergonomic Risk Level Assesment with pulling the wood Final REBA score was 13 and it can be interpreted with very high-risk level. 
4. Levels of Ergonomic Risk with mangampin

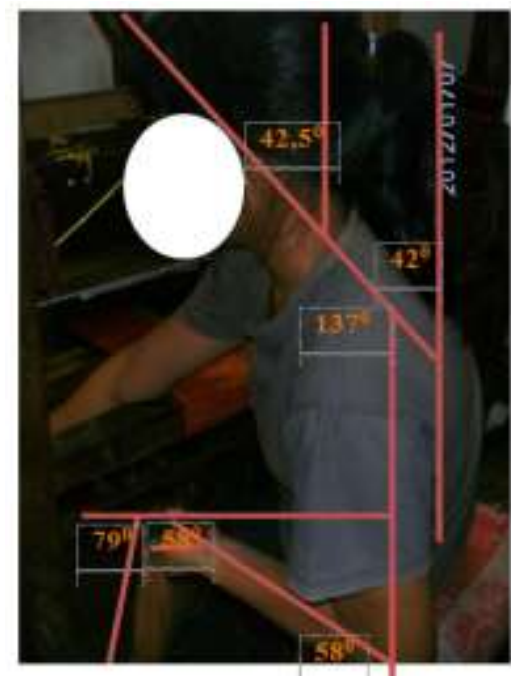

Final REBA score was 8 and it can be interpreted with high-risk level.

\section{IV.DISCUSSION}

\section{a. Level of Ergonomic Risk of Ulos}

\section{Weaving Workers}

Based on the calculation of ergonomic risk level of Ulos woven worker in Martimbang Village and Kebun Sayur shows ergonomic risk level from medium to very high risk. This suggests that the ergonomic risks in ulos weaving work have an ergonomic hazard so that an improvement effort is needed.

In REBA worksheets other than group body parts there are also groups such as burden, handle and activity. The load on this ulos weaving work is less than 11 lbs. So the load has no contribution to the cause of ergonomic risk.

For handling conditions there are three stages that have a handle that is the stage of inserting pakkan, pulling wood and mangampin. But the results obtained for these three stages are different. To enter the packing stage, the object held by the binoculars is still good so the score given is zero.

As for the stage of pulling wood, the handle is the wood. The drawn wood is not ideal but still acceptable by other body parts are so given a score of 1 . And for the mangampin stage, the handle is a pangampin tool. The location of the pangampin is not parallel to the normal condition of the human body in a sitting position so it requires the worker to spin and bend. This condition gets a score of 2 because it is included in the bad category (poor). To stage the tilt, there is no handle so it does not get a score.

At each stage of the ulos weaving work, there is also repetitive movement such as at the stage of tipping, pulling wood and mangampin. To stage the tilt and pull the wood, repetitive movement more than 4 times per minute so that each of these stages gets a score of 1. Repetitive movement at 2 stages is done with fast action causing major changes in various postures. And for this quick movement gets a score of 1 . Repetitive movement and fast action are done in the adjacent time so that greatly affect the score of activity. The mangampin stage is only three times but not in minutes so it does not get a score. For the insert stage, there is absolutely no repetitive movement so 
the activity score for this stage does not exist.

The results of the research which have been described are arranged in table 1 which shows the ergonomic risk level of Ulos weaving work in Martimbang Village and Kebun Sayur Pematang Siantar.

\section{b. Comparison of Ergonomic Risk Levels per Job Stage}

Based on the final REBA score, it can be made a comparison of ergonomic risk level per stage of ulos weaving work.

Table 1 Levels of Ergonomic Risk in Ulos Weaving Workers

\begin{tabular}{llc}
\hline No. & \multicolumn{1}{c}{ Stage } & $\begin{array}{c}\text { REBA } \\
\text { final } \\
\text { score }\end{array}$ \\
\hline 1. & pakkan & 7 \\
2. & Manjungkit & 10 \\
3. & Pulling the wood & 13 \\
4. & Mangampin & 8 \\
\hline
\end{tabular}

Based on the above table, it can be seen that the level of ergonomic risk per job phase. The analysis is as follows:

1. The highest level of employment risk based on the final REBA score is at the stage of pulling the wood. This stage falls into the very highrisk category. This is due to the repetitive movement of pulling wood. The drawn timber is done in a rapid motion so that the worker changes the awkward posture in the adjacent time. The pulled timber also affects the movement of the foot which automatically moves up and down in sync with the pulling of the wood. The foot movement factor also adds an awkward change of posture in the adjacent time so that it affects the activity score. This stage has a high frequency. Workers can withdraw timber 10 times within 1 minute. As for the duration, there is no position of the body part that is static because for the stages of work pulls the wood all the body part to move because it requires a fast action for ulos ulos woven. For the load is less than $5 \mathrm{~kg}$. The wood load is only $2 \mathrm{~kg}$ so it does not get the load score. Although the load is drawn only $2 \mathrm{~kg}$, it can contribute to the increased risk of ergonomics because weaving work is done every day and also need maximum mobilization.

2. Manjungkit also included into high risk with REBA final score is 10 . This is due to the repetitive movement of inserting or linking the thread to the weaving comb. This repetitive movement causes a great change in various postures, especially if it is done by workers who have long worked as ulos weavers. This stage has a high frequency. Workers can perform the staggering stages as much as 18 
times within 1 minute. And this is done with fast motion. As for the duration, there is no position of body parts that are static. This stage has no load.

3. Manjungkit is included in the high risk with REBA final score is 8 . The high score is obtained because of the odd posture is the spine position that rotates to the left side where the pangampin tool is located on the left side of the loom and below the normal posture sitting from the worker so that requires workers to spin and bend. This stage is done not as often as the stage of attracting wood and mangampin. This stage is done in less than a minute. For the duration has no static position and also has no load. Mangampin load only when tightening against ulos to be more dense and maximal results. The load is less than $5 \mathrm{~kg}$ so it does not get a score.

4. The lowest level of ergonomic risk with a final REBA score of 7 lies at the stage of inserting the pack into the binoculars. This stage is included in the medium risk. This is because it is a short process and is not done as often as the stage of pulling wood and stirring. There is also no odd posture in the adjacent time span. This stage is done in less than a minute. For the duration has no static position and also has no load.

\section{c. Analysis of Ulos Weaving Works}

The ulos weaving work has four stages and each stage of the work has an awkward posture. The clumsy posture will increase the workload of the muscles so that it is a significant contributor to skeletal muscle disorders [6]. In addition to increasing the energy required it also causes the transfer of muscle power to the skeletal system becomes inefficient [7].

The odd posture above one of the supporting factors is that during work, the worker sits on a chair that does not use a backrest. As a result, workers bend at work because the body will naturally adapt to the facilities used. This situation causes a forced attitude when workers work using the loom. If this happens over a long period of time, there will be an accumulation of complaints that may eventually lead to muscle injury [8]. The odd posture will increase the workload of the muscles so it is a significant contributor to skeletal muscle disorders. In addition to increasing the energy required it also causes the transfer of muscle power to the skeletal system becomes inefficient [9].

Suma'ur states that working while sitting if the position is done bending is not good for digestion and can cause the back muscles to become tired quickly, 
muscle tension and eventually arise pain [10]. This is related to the increased pressure between the vertebrae when sitting, especially if done with bending [11]. If it is assumed that the pressure is about $100 \%$, the tense and erect posture can cause the pressure to reach $140 \%$ and the way the sitting performed by bending forward causes the pressure to be $190 \%$ [12].

Ulos weaving workers work with monotonous work attitude for long periods of time. After sitting for 15 to 20 minutes, the back muscles usually begin to wear out and Samara also suggests that sitting upright and bending over a period of more than 30 minutes can lead to back pain [13]. Lack of relaxation or stretching of the muscles during work can also cause discomfort that leads to muscle pain [14].

Working in static positions with awkward posture for long periods of time can restrict blood flow to muscle tissue so that oxygen and glucose supply is also constrained. Thus, the muscle will use more energy reserves and creatine phosphate. This will cause pain and pain resulting from the production of lactic acid that accumulates in muscle tissue [15]. Working with awkward posture will increase the amount of energy needed to do the job. The odd posture causes a condition in which the transfer power from the muscle to the skeletal network is inefficient resulting in fatigue [16].

Repetitive movements that occur can increase the use of muscles in the arm that can cause fatigue in the muscle [17]. If this condition persists, it will be potentially affected by carpal tunnel syndrome and tenosynovitis [18].

\section{CONCLUSIONS}

The ulos weaving work in Martimbang Village and Vegetable Garden has four stages of work: putting the pakkan into binoculars, stitching, pulling wood and mangampin. The level of ergonomic risk at each stage of work has a different REBA final score. The ultimate REBA final score is at the stage of pulling the wood with the final REBA score is 13 and need a change.

\section{REFERENCES}

[1]. Effendi F. Ergonomi Bagi Pekerja Sektor Informal. Cermin Dunia Kedokteran No.154. 2007.

[2]. Health and Safety Executive United Kingdom (HSE UK). Understanding ergonomics at work: Reduce accidents and ill health and increase productivity by fitting the task to the worker. Available from: URL:http://www.hse.gov.uk, Accessed October 11, 2011.

[3]. Homsombat, Thanyawat dan Sunisa Chaiklieng. Musculoskeletal and Upper Limb Disorders among Informal Sector Broom Weaving Workers. KKU J.PHR. 2010; Vol.3 No.2.

[4]. Choobineh A, Musculoskeletal Problem in Iranian Hand-Woven Carpet Industry: Guidelines for Workstation Design. Applied Ergonomics 38; pg. 617624.2007. Available from URL: 
http://schealth.sums.ac.ir/icarusplus/exp ort/sites/school-of-

health/department/occupational-

health/personal/pdf-

art/chobien/MSDsat-handwovenindustr-Appl-Ergon.pdf.

[5]. Rosalina, Sinta Dwi. 2011. Analisis Faktor-Faktor yang Berhubungan Dengan Kejadian Musculoskeletal Disorders Segmen Lengan, Bahu dan Kaki Pada Pekerja Tenun Ikat Industri $X$ di Kabupaten Jepara. Skripsi. Fakultas Kesehatan Masyarakat. Universitas Diponegoro.

[6]. Pheasant, Stephen. Body Spaces: Second Edition, Great Britain: TJ International Ltd. Padstow Cornwall. 1999.

[7]. Bridger, R. S. Introduction to Ergonomics, $2^{\text {nd }}$ Ed. Tailor \& Francis Group, London. 2003.

[8]. Tarwaka, Bakri dan Solichul. Ergonomi Untuk Keselamatan, Kesehatan Kerja dan Produktivitas. Jakarta. UNIBA Press. 2004.

[9]. Suma'mur. Higiene Perusahaan dan Kesehatan Kerja (HIPERKES). Jakarta. 2009.

[10]. Nurmianto, E.. Ergonomi Konsep dasar dan Aplikasinya, Surabaya: Guna Widya. 2004.

[11]. Humantech. Managing Ergonomics As A Process: The VVP Safety System. $20^{\text {th }}$ Annual National VPPPA Conference. 2004; Available from URL:http://vpp.pnnl.gov, Accessed November 17, 2011.
[12]. NIOSH. Musculoskeletal Disorders and Workplace Factors: A Critical Review of Epidemiologic Evidence for WorkRelated Musculoskeletal Disorders. NIOSH: Centers for Disease Control and Prevention. 1997.

[13]. Samara, D.. Duduk Lama Dapat Sebabkan Nyeri Pinggang Bawah. Rubrik Kesehatan Kompas Jumat, 2003.

[14]. Tirtayasa. The Change of Working Posture in Manggur Decreases Cardiovascular Load and Musculoskeletal Complaints Among Balinese Gamelan Craftsmen; [online] 2003. Available from: URL:http://www.humanergology.com. Accessed December 22, 2011.

[15]. Pulat, B.Mustafa. Fundamentals of Industrial Ergonomics. New Jersey. Prentice Hall, Inc. 1992.

[16]. Oborne, D.J. Ergonomics at Work. 3rd ed. Chichester: John Wiley \& Sons Ltd. 1995.

[17]. American Dental Association. 2004. An Introduction to Ergonomics: Risk Factors, MSDs, Approaches, and Interventions; Available from: URL:. http://www.ada.org/prof/prac/wellness/e rgonomics_paper.pdf. Accessed Juni 12, 2012.

[18]. Rajnarayan. Low Back Pain among Textile Workers. Indian Journal of Occupational and Environmental Medicine. Vol.7 No.1. January-April. 2003. 